\title{
Porous Lattice Structure of Femoral Stem for Total Hip Arthroplasty
}

\author{
Estructura de Diseño Poroso por Latice de Vástago Femoral para Artroplastia Total de Cadera
}

\author{
L. A. Acosta-Sánchez', A. I. Botello-Arredondo', M. D. Moya-Bencomo² , E. S. Zúñiga-Aguilar ${ }^{1}$ \\ 'Universidad Autónoma de Ciudad Juárez \\ 2Instituto Tecnológico y de Estudios Superiores de Monterrey
}

\begin{abstract}
Total Hip Arthroplasty (THA) is one of the surgical procedures carried out satisfactorily in procedures for osteoarthritis and trauma lesions. ATC surgery reduces pain and improves the quality of life of young patients. Therefore, it is of great importance to improve the properties of hip implants, since current implants do not match their lifespan with the life expectancy of a young patient. This is because the solid prostheses that currently exist have a higher Young's modulus, and therefore are too rigid compared to the bone tissue. On the other hand, the cyclic and continuous loads to which the hip joint is subjected in daily activities, can cause loosening and consequent implant loss The present work proposes an implant manufactured with a porous lattice structure, which aims to reduce stiffness, allow bone growth and a more effective mechanical load transfer. Three computational models subjected to static charges were evaluated and compared: 1 ) healthy femur, 2) implanted femur with a commercial prosthesis, and 3) implanted femur with a prosthesis with lattice structure. For the computational analysis it was decided to perform a static analysis of a person standing on the left foot; a load equivalent to the body weight was applied on the head of the femur, balancing the reaction forces in the system of forces (contact force, body weight, and abductor muscle).. The results were shown in terms of displacement, compression and deformation. The model implanted with a prosthesis with a lattice design presented a slight decrease in displacement, and a decrease in compression and deformation values, which indicated that the proposed design has a better distribution and transport of the loads through its structure.
\end{abstract}




\section{RESUMEN}

La artroplastia total de cadera (ATC) es uno de los tratamientos quirúrgicos llevados a cabo de manera satisfactoria en procedimientos para la osteoartritis y lesiones de trauma. La ATC reduce el dolor y mejora la calidad de vida de los pacientes. Por lo tanto, es de gran importancia mejorar las propiedades de los implantes de cadera, ya que los implantes actuales tienen un tiempo de vida útil y deben cumplir con las expectativas de rehabilitación para los pacientes. Esto se debe a que las prótesis sólidas que existen actualmente tienen un módulo de Young más elevado, y por lo tanto son demasiado rígidas a comparación del tejido óseo. Por otro lado, las cargas cíclicas y continuas a las que se ve sometida la articulación de la cadera en actividades diarias, pueden ser causa del aflojamiento y consecuente pérdida del implante. El presente trabajo propone un implante fabricado con una estructura porosa tipo látice, el cual tiene como objetivos reducir la rigidez, permitir crecimiento óseo y una transferencia de cargas mecánicas más efectiva. Se evaluaron y compararon tres modelos computacionales sometidos a cargas estáticas: 1) fémur sano, 2) fémur implantado con una prótesis comercial, y 3) fémur implantado con una prótesis con estructura látice. Para el modelo computacional se optó por hacer un análisis estático de una persona parada sobre el pie izquierdo; donde se aplicó una carga equivalente del peso corporal sobre la cabeza del fémur, equilibrando las fuerzas de reacción en el sistema de fuerzas (fuerza de contacto, peso corporal, y músculo abductor). Los resultados fueron mostrados en términos de desplazamiento, compresión y deformación. El modelo implantado con una prótesis con un diseño tipo látice presentó una ligera disminución de desplazamiento, y disminución en los valores de compresión y deformación, lo que indicó que el diseño propuesto posee una mejor distribución y transporte de las cargas a través de su estructura.

PALABras CLAVE: Artroplastia Total de Cadera; Vástago Femoral; Látice; Análisis por Elemento Finito

\section{Correspondencia}

DESTINATARIO: Dr. Adeodato Israel Botello Arredondo INSTITUCIÓN: Universidad Autónoma de Ciudad Juárez DIRECCIÓN: Av. Del Charro \#450 Norte, Col. Partido Romero, C. P. 32310, Ciudad Juárez, Chihuahua, México CORREOELECTRÓNICO: adeodato.botello@uacj.mx

\section{Fecha de recepción:}

15 de junio de 2019

Fecha de aceptación:

12 de enero de 2020 


\section{INTRODUCTION}

Total Hip Arthroplasty (THA), is one of the most successful surgical treatments for osteoarthritis [1][2]. More than half a million THA procedures take place in the United States and United Kingdom per year. The surgery involves the resection of the neck and head of the femur and part of the acetabulum cup in order to introduce an implant to replace the structure and function of the joint ${ }^{[3]}[4]$.

Bones are exposed to frequent mechanical stimulation and they have the ability to reorganize their own topology and adapt to the loads applied over osseous structure. This principle, known as the Wolff Law, states that the osseous remodelling (deposition or reabsorption of bone tissue) depends on the amount of mechanical stimulation ${ }^{[5]}$. However, when an implant is introduced in the femur, bone resorption (loss of adjacent bone) may appear due to stress shielding. Stress shielding is an undesirable result of the difference in stiffness between the prothesis and the natural material they replace ${ }^{[6]}$.

Mechanically speaking, it is necessary that the hip implant withstands the mechanical loads inside the hip during daily activities. To avoid progressive and allocated damage, various design techniques have surfaced to create a new type of hip implant made with microstructure of a cell-like array. This means that instead of being a totally solid implant, it is a material manufactured by layers with pores. Modifying the structural properties of the implant causing a reduction of the stiffness. This will reduce stress shielding and prevents osteolysis. In addition, the optimization of pore size in the implant could improve the deformation interface between bone and implant ${ }^{[7]}$.

The life expectancy of young patients who undergo TCA is a problem when it does not match the lifetime of commercial implants, this is due to the difference in the value of modulus of rigidity between implant (femoral stem) and bone tissue, which results in an increase of stress shielding and bone resorption, which in time leads to implant loss and therefore a revision surgery is needed. The rigidity of metallic stem implants could be reduced by using porous structures. These porous structures could also promote osseointegration, and achieve a long term fixation which would avoid the problems of a revision surgery ${ }^{[8]}[9]$.

Finite Element Analysis (FEA) is a very powerful tool that enables exploring possible solutions to biological problems. FEA makes it possible to predict the mechanical behaviour of hip implants. The computational simulation by finite element depends on several parameters such as: geometry, material properties, boundary conditions and constraints ${ }^{[10]}$.

Additive manufacturing (AM) is the process of creating a three-dimensional object layer by layer by deposition of material. Usually, additive manufacturing techniques melt powder material to create parts with an internal network as structure. Two techniques are currently used: SLM (Selective Laser Melting) and EBM (Electron Beam Melting) ${ }^{[11]}$.

\section{METODOLOGY}

For this study a 3D scan geometrical model from a Sawbones ${ }^{\circledR}$ composite synthetic left femur was used. The geometry possessed two types of tissue; cortical and trabecular bone. The numerical analysis was performed in 3 models: healthy femur, femur implanted with a commercial prosthesis (Corail DePuy ${ }^{\circledR}$, size 11), and femur implanted with a modified prosthesis with lattice structure. For the implantation, a cut was made in the healthy femur where the head and neck of the femur was dissected at $1.5-2 \mathrm{~cm}$ above the great trochanter towards the level of the piriform fossa, approximately at $35^{\circ}$ of the longitudinal axis of the femur. The stem was virtually implanted according to the instructions of the company brochure and medical advice. 
The solid femoral stem (DePuy ${ }^{\circledR}$ Corail size 11) shown in Figure 1, was used for the second analysis. For the third analysis, the stem geometry was modified with a creation of a lattice structure (Figure 2), through out a series of pores of diameter of $0.31 \mathrm{~mm}$.

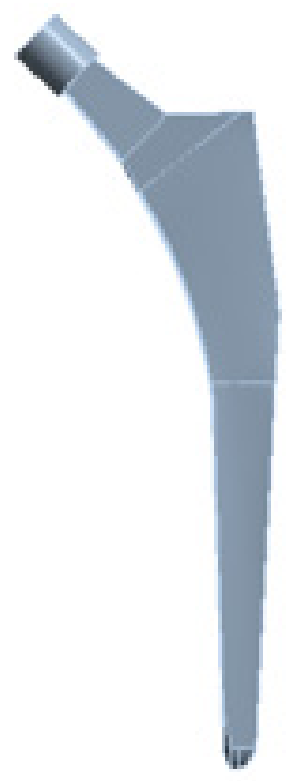

FIGURE 1. Femoral Stem Corail DePuy ${ }^{\circledR}$ size 11, viewed at plane $X Z$.

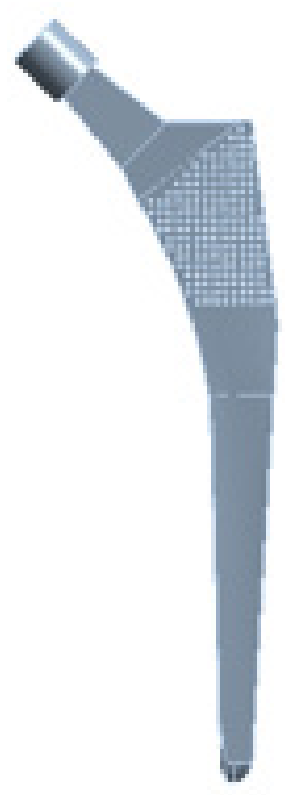

FIGURE 2. Modified femoral stem with porous lattice structure, views at plane XZ.

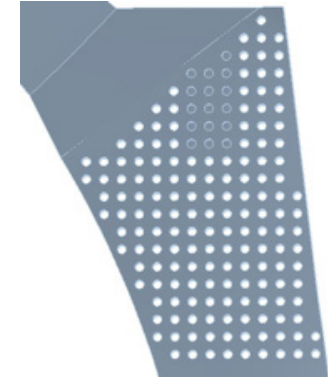

FIGURE 3. Modified femoral stem with porous lattice structure, close up view at plane XZ.

These porous series consisted in two lattice arrays. The first array was done in the frontal plane (XZ) at the proximal a zone of the femoral stem, just below the area that protrudes from the dissected region of the femur model. The second array arrangement was placed in the plane YZ so that they coincide with the pores made in the plane XZ resulting in the geometry shown in Figure 3.

TABLE 1. Mechanical properties of materials.

\begin{tabular}{|c|c|c|c|}
\hline $\begin{array}{c}\text { Element } \\
\text { Material }\end{array}$ & $\begin{array}{c}\text { Young's } \\
\text { Modulus } \\
\text { (GPa) }\end{array}$ & $\begin{array}{c}\text { Poisson's } \\
\text { Ratio }\end{array}$ & $\begin{array}{c}\text { Density } \\
\text { (kg/cm } \mathbf{3}\end{array}$ \\
\hline $\begin{array}{c}\text { Cortical } \\
\text { bone }\end{array}$ & 17 & 0.3 & 1740 \\
\hline $\begin{array}{c}\text { Trabecular } \\
\text { bone }\end{array}$ & 0.07 & 0.2 & 730 \\
\hline $\begin{array}{c}\text { Implant } \\
\text { Ti6Al4V }\end{array}$ & 114 & 0.3 & 4440 \\
\hline $\begin{array}{c}\text { Head of implant } \\
\text { CoCrMo }\end{array}$ & 220 & 0.33 & 8830 \\
\hline $\begin{array}{c}\text { Acetabular } \\
\text { cup }\end{array}$ & 17 & 0.3 & 1740 \\
\hline
\end{tabular}

Once the 3 FEA models were prepared, the properties of the materials and the boundary conditions used for the simulations were introduced in a CAE Software, ANSYS Workbench $16^{\circledR}$. For this study, the properties of the materials were considered as elastic and isotropic. For the static analysis, each model had a set of forces acting on the biomechanical system, which represent in a simplified way the forces resulting from a person standing on his left leg. The boundary conditions are shown in Table 2 and Figure 4. 
TABLE 2. Boundary conditions for the analysis.

\begin{tabular}{|c|c|} 
Condition & \multicolumn{1}{|c|}{ Description } \\
\hline Interactions & $\begin{array}{l}\bullet ! \text { Cortical and trabecular bone perfectly bonded at the } \\
\text { interface. } \\
\bullet ! \text { Femoral head and acetabular cup perfectly bonded. }\end{array}$ \\
\hline Body Weight & $\begin{array}{l}\cdot ! \text { Force components standing on one foot }(\mathrm{N}): \\
\text { Fx=-350 N Fz= } 1518 \mathrm{~N} \\
\bullet ! \text { Force applied at to the head of the femur by the } \\
\text { acetabular cup. }\end{array}$ \\
\hline Muscle & $\begin{array}{l}\bullet ! \text { Force components of the abductor muscle }(\mathrm{N}): \\
\text { Fx=350 N Fy= -962 N }\end{array}$ \\
\hline Constants & $\begin{array}{l}\cdot ! \text { Acetabular cup: Solid geometry, free displacement } \\
\text { in the } \mathrm{Z} \text { axis. } \\
\text { ! Encastre: Femoral condyles were encastrated } \\
\text { (no movement is allowed in the 3 axis). }\end{array}$ \\
\hline
\end{tabular}

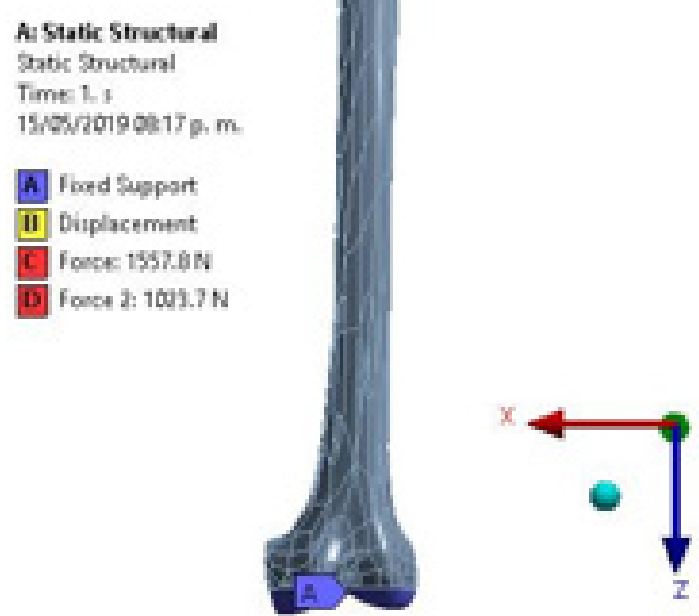

FIGURE 4. Anterior view of boundary conditions and forces acting on the left intact femur.

In the simulation the forces of body weight are applied on an acetabular cup and the force of the greater abductor muscle was located in the greater trochanter region in order to simplify the study ${ }^{[12]}$. The computational model was meshed with tetrahedral volumes, with a maximum size per element of $0.5 \mathrm{~mm}$, resulting in 3587419 nodes and 2127813 elements on average for each of the 3 models.

\section{RESULTS AND DISCUSION}

\section{Displacement}

Femur deformation was evaluated for the three different models (healthy femur, femur implanted with commercial prosthesis, and femur implanted with modified prosthesis with lattice structure, shown in Figure 5 through to Figure 7 respectively). The displacement caused to the models was measured in millimetres which for the model of healthy femur a maximum displacement of $0.281 \mathrm{~mm}$ was obtained. The displacement values of the models implanted with a commercial prosthesis and implanted with a modified prosthesis with a lattice structure were $0.314 \mathrm{~mm}$ for both cases.

The close similarity of the results obtained for maximum displacement in the implanted models may be caused by the fact that the lattice structure did not have the most optimal pore size for this application, since most of the femoral stem still has a solid structure and
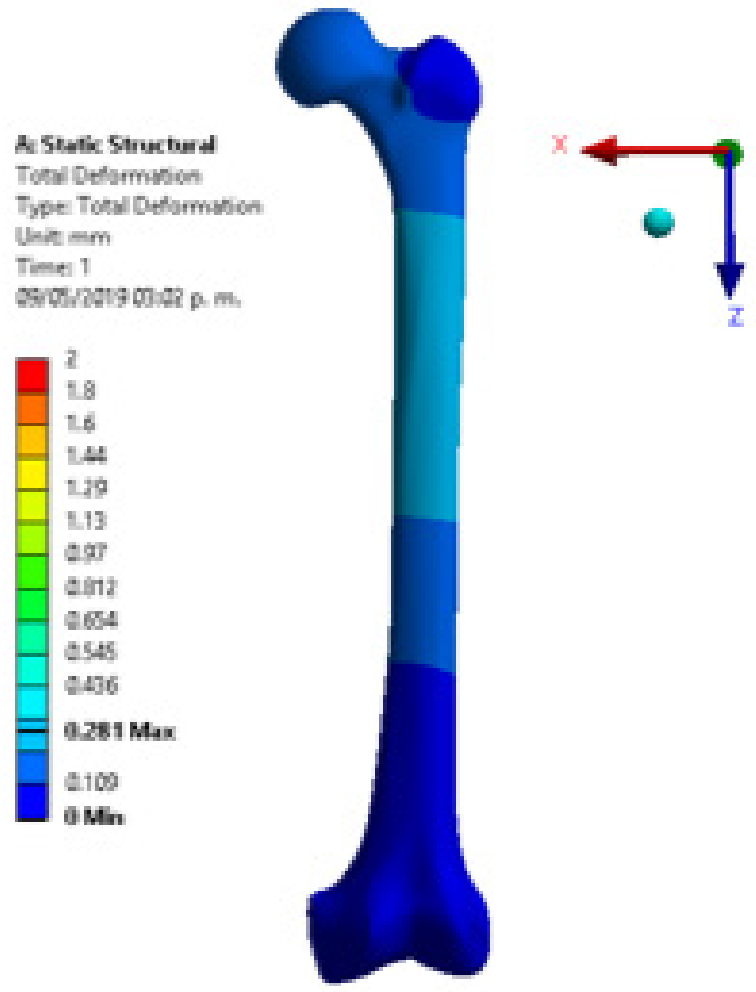

FIGURE 5. Displacement ( $\mathrm{mm})$ healthy femur. 

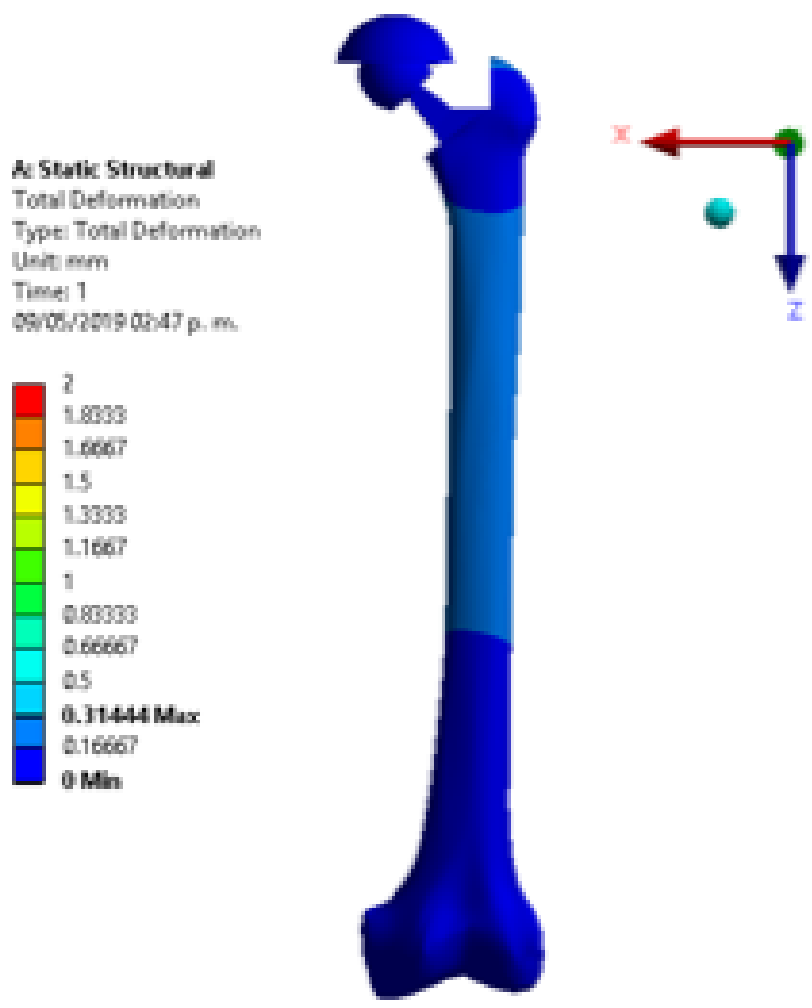

FIGURE 6. Displacement $(\mathrm{mm})$ of the femur implanted with commercial femoral stem.
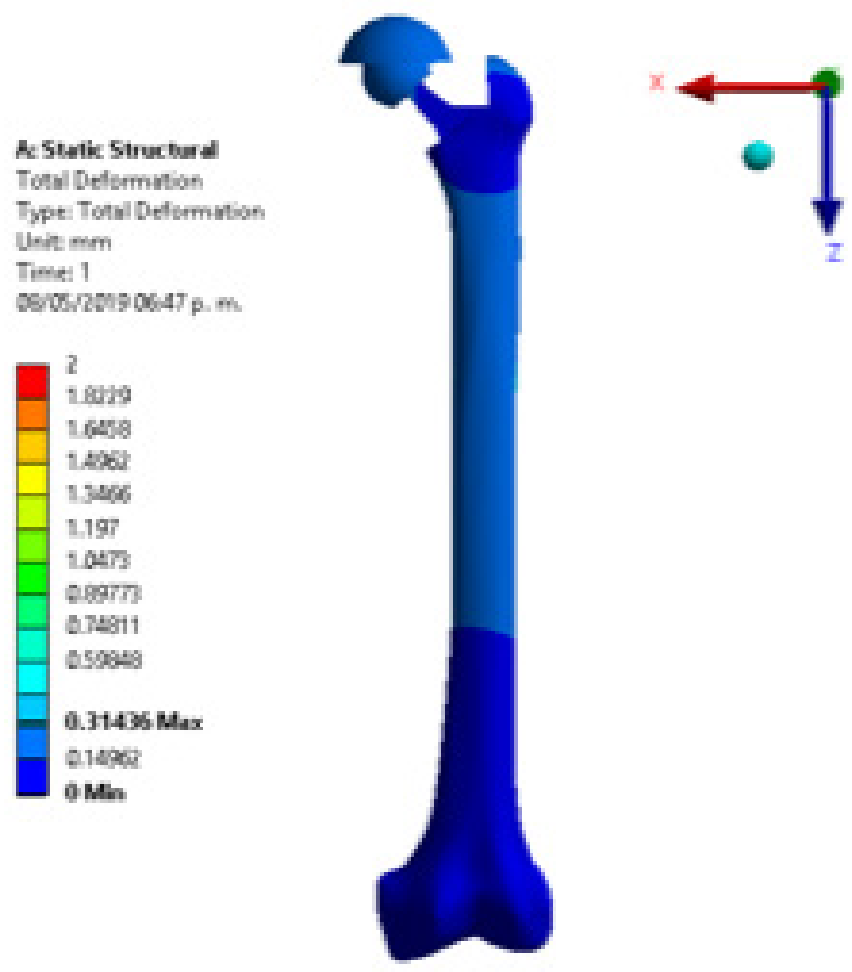

FIGURE 7. Displacement $(\mathrm{mm})$ of the femur implanted with modified femoral stem with lattice structure. identical to the commercial stem, in addition to the lattice geometry used, i.e. circular pores, which might have not been the most suitable geometrical shape for this application and mechanical transfer of loads.

\section{Elastic Strain}

To compare the elastic strain in the different regions of interest, the surfaces of the femur were divided using the Gruen zones, established as shown in Figure 8 through to Figure 11 show the elastic strain obtained in the characteristic tension and compression areas in each model studied. The average values of the elastic strain found in the Gruen zones can be seen in Table 3, Table 4, and Table 5.

The values obtained in the present work for each of the regions of tension and compression are similar to those shown by Moya ${ }^{[12]}$. These values obtained for elastic strain, expressed by the tension and compression regions, are a characteristic behaviour in the structure of the femoral bone. The load distribution performed by the internal trabecular networks achieve this effect by directing the loads to the femur's longitudinal structure (shaft), and to the external periphery ${ }^{[13]}$.

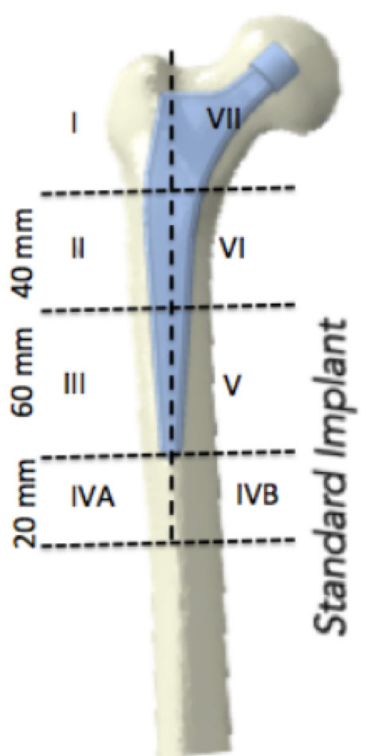

FIGURE 8. Gruen Zones considered for a standard femoral implant. 

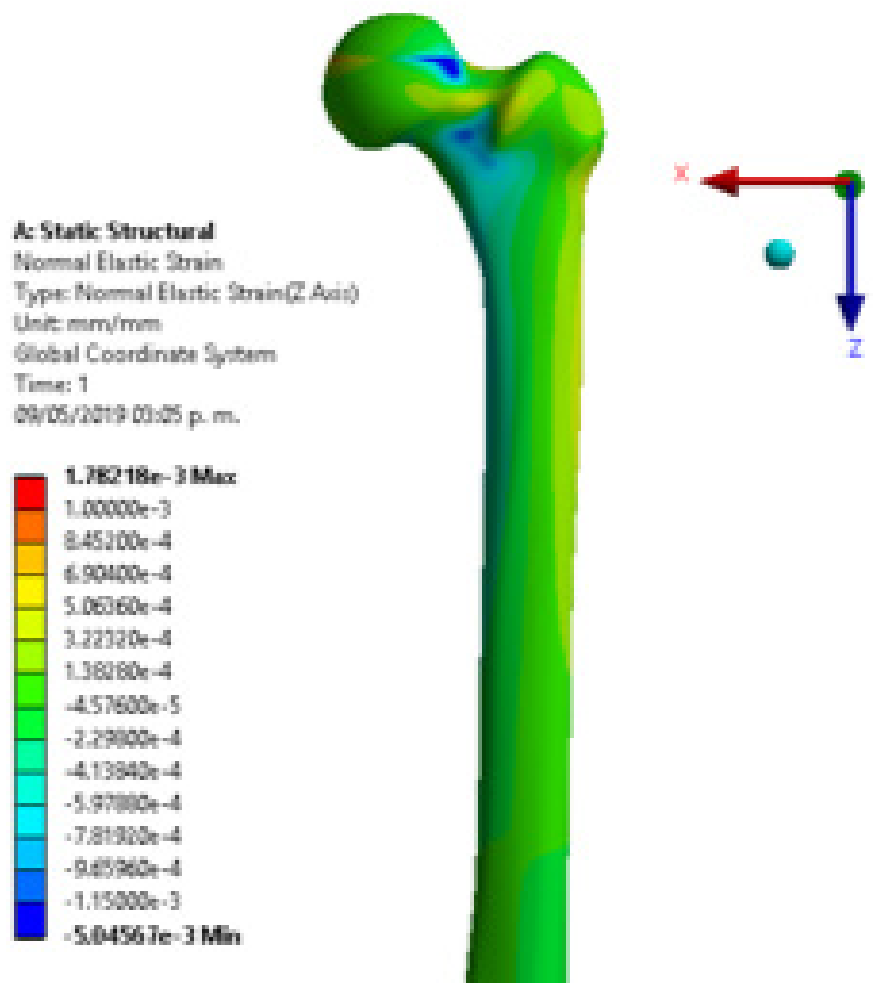

FIGURE 9. Elastic strain $(\mathrm{mm} / \mathrm{mm})$ of the healthy femur.

A: Static Structured Narmal Elasbc 9rain

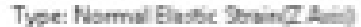
Unit mm/mm Glabd Cocedinate Syitem Time 1

0965/20190252 p. m

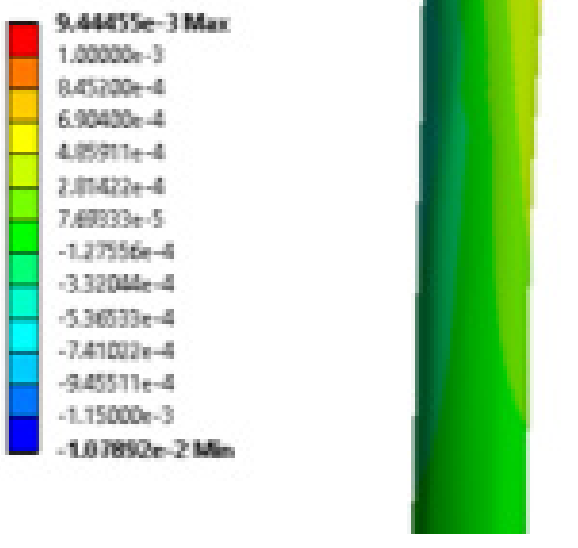

FIGURE 10. Elastic strain $(\mathrm{mm} / \mathrm{mm})$ of femur implanted with commercial femoral stem.

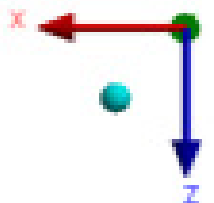

A: Static Structure

Nermal flatic thain

Tyee: Narma Elatic $\$$ bain 2 kaid Unit: mm/mm

Gisbs: Ceondinats Syatem

Time 1

Davsugredi.25 p. m.

1.50246e-2 Max

$1.00000 t-3$

B.25asin-4

$6.51305+4$

$4.72050-4$

$3.03819 t-4$

$1.23162 \mathrm{t}-4$

$-4.42057 \mathrm{k}-5$

$-2.60429-4$

$-4.06571 \mathrm{e}-4$

$-7.00746-4$

$-9.28057 \mathrm{e}-4$

$-1.15000 t-3$

$-1.06006 \mathrm{e}-2$

200551 - $2 \mathrm{Mm}$

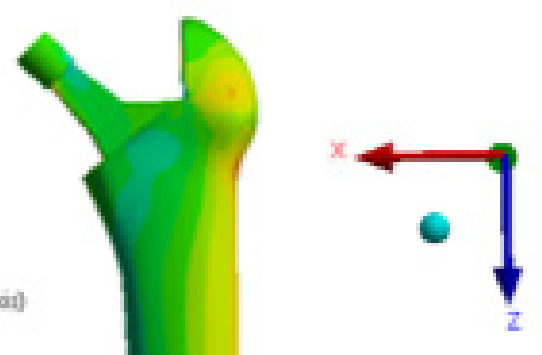

FIGURE 11. Elastic strain $(\mathrm{mm} / \mathrm{mm})$ of femur implanted with modified femoral stem with lattice structure. 
TABLE 3. Average values of elastic strain $(\mathrm{mm} / \mathrm{mm})$ in the healthy femur.

\begin{tabular}{|c|c|}
\hline Zones & Elastic Strain $(\mathbf{m m} / \mathbf{m m})$ \\
\hline I & $3.98 \mathrm{e}-4$ \\
\hline II & $1.91 \mathrm{e}-4$ \\
\hline III & $2.36 \mathrm{e}-4$ \\
\hline IVA & $2.01 \mathrm{e}-4$ \\
\hline IVB & $-4.65 \mathrm{e}-4$ \\
\hline V & $-4.23 \mathrm{e}-4$ \\
\hline VI & $-4.11 \mathrm{e}-4$ \\
\hline VII & $-7.65 \mathrm{e}-4$ \\
\hline
\end{tabular}

TABLE 4. Average values of elastic strain $(\mathrm{mm} / \mathrm{mm})$ of femur implanted with commercial prosthesis.

\begin{tabular}{|c|c|}
\hline Zones & Elastic Strain $(\mathbf{m m} / \mathbf{m m})$ \\
\hline I & $6.17 \mathrm{e}-4$ \\
\hline II & $3.01 \mathrm{e}-4$ \\
\hline III & $3.84 \mathrm{e}-4$ \\
\hline IVA & $3.06 \mathrm{e}-4$ \\
\hline IVB & $-3.69 \mathrm{e}-4$ \\
\hline V & $-3.35 \mathrm{e}-4$ \\
\hline VI & $-2.34 \mathrm{e}-4$ \\
\hline VII & $-1.8 \mathrm{e}-4$ \\
\hline
\end{tabular}

\section{TABLE 5. Average values of elastic strain $(\mathrm{mm} / \mathrm{mm})$ in the femur implanted with the modified prosthesis with lattice structure.}

\begin{tabular}{|c|c|}
\hline Zones & Elastic Strain $(\mathbf{m m} / \mathbf{m m})$ \\
\hline I & $5.85 \mathrm{e}-4$ \\
\hline II & $3.49 \mathrm{e}-4$ \\
\hline III & $3.22 \mathrm{e}-4$ \\
\hline IVA & $3.37 \mathrm{e}-4$ \\
\hline IVB & $-3.79 \mathrm{e}-4$ \\
\hline V & $-2.47 \mathrm{e}-4$ \\
\hline VI & $-2.23 \mathrm{e}-4$ \\
\hline VII & $-1.55 \mathrm{e}-4$ \\
\hline
\end{tabular}

\section{Stress}

Finally, the last point to evaluate was the equivalent stress to analyse the effect of the loads through their structures for the three models. For this, a point at the compression area and at the middle of the proximal region of the femur was selected, the maximum value of stress was compared with the results obtained in the work of Moya ${ }^{[12]}$. The results obtained by Moya, for the healthy femur and femur implanted with a commercial prosthesis were of $16 \mathrm{MPa}$ and $13 \mathrm{MPa}$ respectively.

The intact model seen in Figure 12 showed a superficial stress of 8.9 MPa at the zone of interest. The resulting stress for the model implanted with a commercial prosthesis was of $7.51 \mathrm{MPa}$, and the model implanted with a modified prosthesis with a lattice structure showed a superficial stress of $7.17 \mathrm{MPa}$ at the zone of interest.

The implanted models achieved a considerable reduction of superficial stress compared to the healthy femur. The model implanted with a lattice structure was expected to reduce the superficial stress much more than the model implanted with the commercial prosthesis, but the results are similar to those obtained with the commercial femoral stem. Nevertheless, the model implanted with a modified prosthesis with lattice structure presents a small reduction of stress. 
A: S1atic Structural Equivilent Stress

Type: Equivilent (fwon-Miies) Sresi

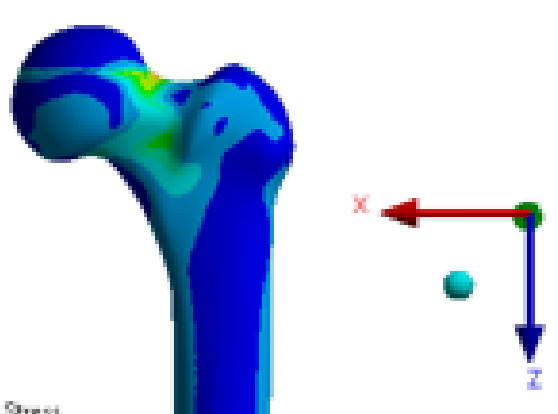
Unit Mro

Time 1

0206/201903:10p. $m$

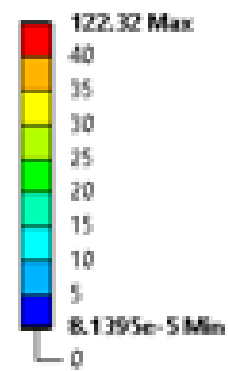

FIGURE 12. Equivalent Stress (MPa) in the

healthy femur.

A: Static Structural Equivalern Soress

Tyes: Equivilent (voo-Mies) Seress Unit Mio

Time: 1

0215/20190254 8. m.

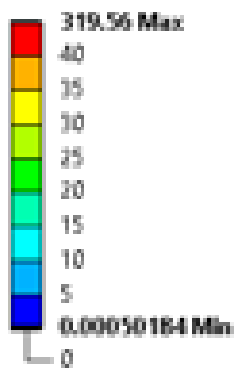

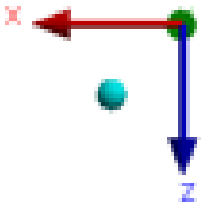

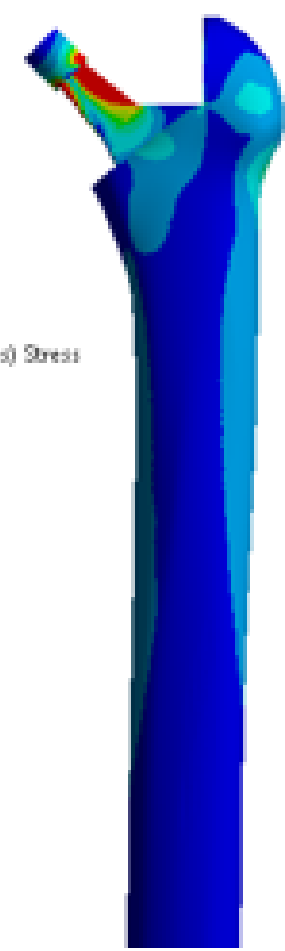

FIGURE 13. Equivalent Stress ( $\mathrm{MPa}$ ) in the femur implanted with commercial prosthesis.
Ac Stutk Strucbura feuvalent teres

Type: feuivalent (ven-Misen fores Unit MP,

Time: 1

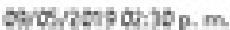
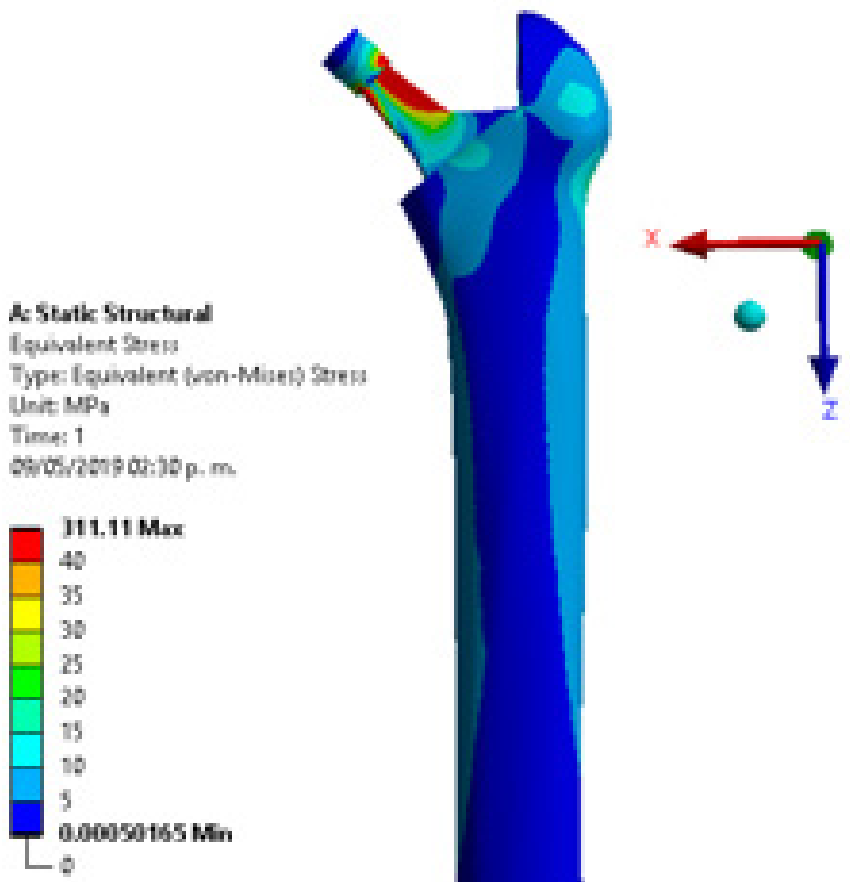

FIGURE 14. Equivalent Stress (MPa) in the femur implanted with modified prosthesis with lattice structure. 


\section{CONCLUSIONS}

The search to create a better design of femoral stem for total hip arthroplasty has led to the implementation of innovative design and manufacturing methods with new geometries, structures and materials. in order to have a closer approach to the mechanical characteristics of a healthy femur, and to improve the implantation of the hip prosthesis, promote osseointegration and prolonging the life of the implant and therefore, to improve the quality of life of the patient.

The results obtained were very similar between the model implanted with a commercial prosthesis and the model implanted with a modified prosthesis with a lattice structure. For this reason, it is necessary to continue making tests with different lattice structures of smaller dimensions in the ranges of 500 microns, and if possible, betting on -nano dimensions. To achieve the objective that the properties of the femoral stem resemble the properties of the osseous tissue of the femur, to avoid high shielding stress, bone resorption and consequently loosening of the implant.

As future work, the objective is to design through lattice structures, an arrangement of artificial trabeculae to efficiently transport and direct the loads through the walls of the femoral shaft. 


\section{REFERENCES}

[1] Breusch S, Malchau H. The Well-Cemented Total Hip Arthroplasty: Theory and Practice [Internet]. Springer; 2005. Available from: http://www.scopus.com/inward/record.url?eid=2-s2.084892029754\&partnerID $=40 \& m d 5=b 7 e 5 a 940 e e d 57 b c 42 c 7777$ cfb386948

[2] Learmonth ID, Young C, Rorabeck C. The operation of the century: total hip replacement. Lancet [Internet]. 2007;370:1508-19. Available from: $h t t p: / / w w w . s c i e n c e d i r e c t . c o m / s c i e n c e / a r t i c l e / p i i /$ S0140673607604577

[3] Pivec R, Johnson AJ, Mears SC, Mont MA. Hip arthroplasty. Lancet [Internet]. 2012;380:1768-77. Available from: http://linkinghub. elsevier.com/retrieve/pii/S0140673612606072

[4] He Y, Durocher D, Burkhalter D, Gilbert JM, Bone W. Solid-Lattice Hip Prosthesis Design: Applying Topology and Lattice Optimization to Reduce Stress Shielding From Hip Implants. 2018;1-5.

[5] Jetté B, Brailovski V, Simoneau C, Dumas M, Terriault P. Development and in vitro validation of a simplified numerical model for the design of a biomimetic femoral stem. J Mech Behav Biomed Mater [Internet]. Elsevier; 2018 [cited 2018 Nov 28];77:539-50. Available from: https://www.sciencedirect.com/ science/article/pii/S1751616117304484

[6] Gargiulo P, Gislason MK, Edmunds KJ, Pitocchi J, Carraro U, Esposito L, et al. CT-Based Bone and Muscle Assessment in Normal and Pathological Conditions. Encycl Biomed Eng [Internet]. Elsevier; 2019 [cited 2019 Jul 13];119-34. Available from: https:// www.sciencedirect.com/science/article/pii/B9780128012383999203

[7] Arabnejad Khanoki S, Pasini D. Fatigue design of a mechanically biocompatible lattice for a proof-of-concept femoral stem. J Mech Behav Biomed Mater [Internet]. Elsevier; 2013 [cited 2018 Nov 28];22:65-83. Available from: https://www.sciencedirect.com/ science/article/pii/S1751616113000805
[8] Jetté B, Brailovski V, Dumas M, Simoneau C, Terriault P. Femoral stem incorporating a diamond cubic lattice structure: Design, manufacture and testing. J Mech Behav Biomed Mater [Internet]. Elsevier; 2018 [cited 2018 Nov 28];77:58-72. Available from: https:// www.sciencedirect.com/science/article/pii/S175161611730382X

[9] Simoneau C, Terriault P, Jetté B, Dumas M, Brailovski V. Development of a porous metallic femoral stem: Design, manufacturing, simulation and mechanical testing. Mater Des

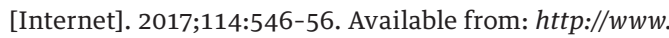
sciencedirect.com/science/article/pii/So264127516313636

[10] Ramos A, Fonseca F, Simões JA. Simulation of Physiological Loading in Total Hip Replacements. J Biomech Eng [Internet]. ASME; 2006;128:579-87. Available from: http://dx.doi. org/10.1115/1.2205864

[11] Burton HE, Eisenstein NM, Lawless BM, Jamshidi P, Segarra MA, Addison $\mathrm{O}$, et al. The design of additively manufactured lattices to increase the functionality of medical implants. Mater Sci Eng C [Internet]. Elsevier; 2019 [cited 2018 Nov 28];94:901-8. Available from: https://www.sciencedirect.com/science/article/pii/ Sog28493118307628

[12] Sciences $P$. The effect of stem length and space slots on stress shielding after Revision Total Hip Arthroplasty ( RTHA ) Marcos David Moya Bencomo. 2016;

[13] Skedros JG, Baucom SL. Mathematical analysis of trabecular "trajectories" in apparent trajectorial structures: The unfortunate historical emphasis on the human proximal femur. J Theor Biol. 2007;244:15-45. 